\title{
AN ANALYSIS OF THE TECHNICAL AND ECONOMIC PERFORMANCE OF A PARABOLIC TROUGH CONCENTRATOR FOR SOLAR INDUSTRIAL PROCESS HEAT APPLICATION
}

\author{
J. A. Clark \\ Department of Mechanical Engineering and Applied Mechanics, University of Michigan, Ann Arbor. \\ MI 48109, U.S.A.
}

(Received 30 March 1982)

\begin{abstract}
An identification of the principal design factors that influence the technical performance of a parabolic trough concentrator and which relate directly to design and manufacturing decisions is presented. These factors include spectral-directional reflectivity of the mirror system, the mirror-receiver tube intercept factor, the incident angle modifier and absorptivity-transmissivity product of the receiver tube and cover tube, the end loss factor and a factor describing the effect of tracking crrors and recciver tube misalignment. Each of these factors has been quantified in terms of design and manufacturing tolerances and associated performance degradation. Other design considerations that relate to thermal loss from the receiver tube are low emissivity coatings, evacuation and anti-reflection coating.

The analysis of energy costs using the parabolic trough concentrator is developed. This analysis determines both the break-even, current metered cost of energy and the annual cash flow over periods of investment ranging from 5 to $15 \mathrm{yr}$. The economic factors include investment tax credit, energy equipment tax credit, income tax bracket, cost of auxiliary system, foundations and controls, cost of collector at installation, costs of maintenance and taxes, costs of fuel, cost of capital, general inflation rate and fuel escalation rate. Economic determinations were made at three U.S. locations: Albuquerque, New Mexico; Fresno, California ; and Caribou, Maine using the thermal performance characteristics of the Sandia Advanced Trough Prototype Collector. The collector costs used were those determined by a manufacturing cost analysis for various manufacturing volumes up to 100000 modules (each $516 \mathrm{ft}^{2} ; 48 \mathrm{~m}^{2}$ ) per year.

The results show that for a $10 \mathrm{yr}$ period of investment, the current metered breakeven costs are less than $\$ 7.00$ per $10^{6}$ BTU at all locations for a collector having a total installed cost of $\$ 15.79 \mathrm{ft}^{-2}\left(\$ 170.00 \mathrm{~m}^{-2}\right)$, which includes manufacturing and installation (\$11.50), foundations, and controls $(\$ 1.50)$ and auxiliary system (\$2.79). For a $15 \mathrm{yr}$ period of investment the corresponding fuel costs are less than $\$ 4.00$ per $10^{6} \mathrm{BTU}$ at all locations.

For a total installed collector cost of $\$ 22.79 \mathrm{ft}^{-2}\left(\$ 245 \mathrm{~m}^{-2}\right)$, the break even metered fuel cost is less than $\$ 9.00$ per $10^{\circ} \mathrm{BTU}$ at all locations, also for a $10 \mathrm{yr}$ period of investment. Other conditions are evaluated. The analysis is general which permits other circumstances to be evaluated.
\end{abstract}

\section{NOMENCLATURE}

$A_{\mathrm{c}}$

$A_{0}$

a,

$a$,

$C_{c}$

$C_{\mathrm{sc}}$

$C_{0}$,

$C_{0}^{\prime}$

$C_{\mathrm{E}}$,

price

$C_{\mathrm{E}}^{\prime}, \quad\left(1-C_{\mathrm{i}}-C_{\mathrm{T}}\right) C_{\mathrm{E}}[\$]$

$C_{\mathrm{i}}$, investment tax credit (1);

$C_{\mathrm{T}}$, energy equipment tax credit (1);

$C_{\mathrm{S}}, \quad$ income tax bracket (1);

$C_{\mathrm{Fo}}$, current metered tuel price $\left[\$ \mathrm{BTU}^{-1}, \$ \mathrm{GJ}^{-1}\right]$;

$C_{\mathrm{F}_{0},}^{\prime}, \quad\left(1-C_{\mathrm{S}}\right) C_{\mathrm{F}_{0}}$;

$D_{0}, \quad$ diameter of receiver $[\mathrm{ft}, \mathrm{m}]$;

$F_{\mathrm{R}}, \quad[4]$;

$f$. focal length $[\mathrm{ft}, \mathrm{m}]$;

$F_{\mathrm{s}}$, fraction of annual load provided by solar (1);

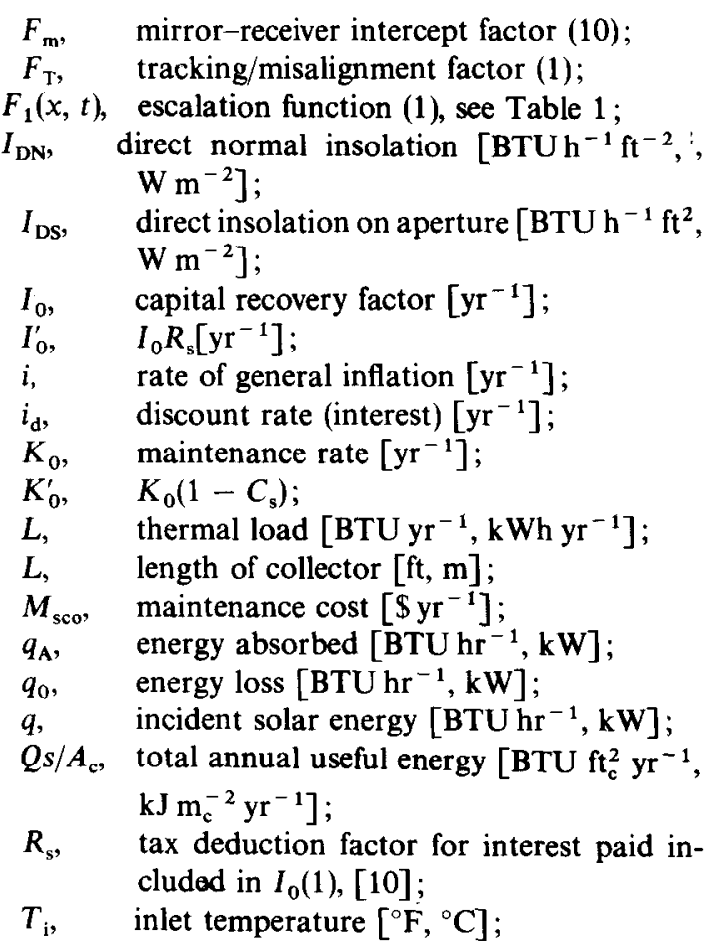

$F_{\mathrm{m}}, \quad$ mirror-receiver intercept factor $(10)$;

$F_{1}(x, t)$, escalation function (1), see Table 1 ;

$\left.\mathrm{W} \mathrm{m}^{-2}\right]$

$I_{\text {DS }} \quad$ direct insolation on aperture $\left[\mathrm{BTU} \mathrm{h} \mathrm{h}^{-1} \mathrm{ft}^{2}\right.$, $\mathrm{W} \mathrm{\textrm {m } ^ { - 2 }}$ ];

$I_{0}, \quad$ capital recovery factor $\left[\mathrm{yr}^{-1}\right]$

$I_{0}^{\prime}, \quad I_{0} R_{\mathrm{s}}\left[\mathrm{yr}^{-1}\right]$;

$i$, rate of general inflation $\left[\mathrm{yr}^{-1}\right]$

$i_{\mathrm{d}}, \quad$ discount rate (interest) $\left[\mathrm{yr}^{-1}\right]$;

$K_{0}, \quad$ maintenance rate $\left[\mathrm{yr}^{-1}\right]$

$K_{0}^{\prime}, \quad K_{0}\left(1-C_{\mathrm{s}}\right)$;

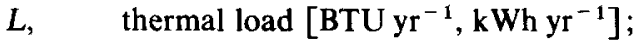

$L, \quad$ length of collector $[\mathrm{ft}, \mathrm{m}]$;

$M_{\text {sco }}, \quad$ maintenance cost $\left[\$ \mathrm{yr}^{-1}\right]$;

$q_{\mathrm{A}}, \quad$ energy absorbed [BTU hr $\left.{ }^{-1}, \mathrm{~kW}\right]$;

$q_{0}, \quad$ energy loss [BTU hr ${ }^{-1}, \mathrm{~kW}$ ];

$q, \quad$ incident solar energy [BTU $\left.\mathrm{hr}^{-1}, \mathrm{~kW}\right]$;

$Q s / A_{\mathrm{c}}$, total annual useful energy $\left[\mathrm{BTU} \mathrm{ft}_{\mathrm{c}}^{2} \mathrm{yr}^{-1}\right.$,

$R_{\mathrm{s}}$, tax deduction factor for interest paid in-

$T_{\mathrm{i}}, \quad$ inlet temperature $\left[{ }^{\circ} \mathrm{F},{ }^{\circ} \mathrm{C}\right]$; 


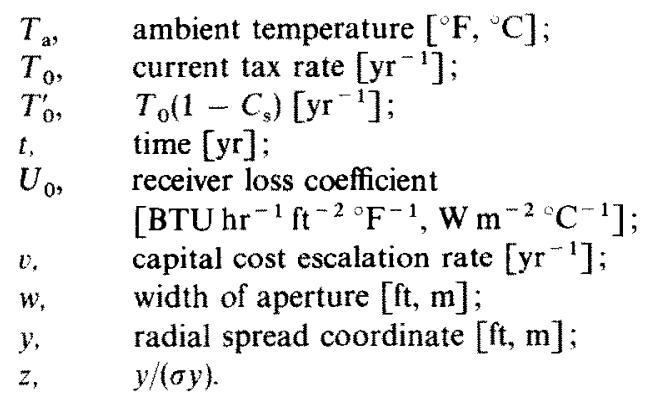

Greek symbols

$\begin{array}{ll}\sigma_{\theta}, & \text { equation }(12)(1) ; \\ \sigma_{y}, & \text { equation }(13)(1) ; \\ \alpha, & \text { absorptivity }(1) ; \\ \tau, & \text { transmissivity }(1) ; \\ \psi_{1}, & \text { mirror beam spread }(1) ; \\ \psi_{2}, & \text { solar beam spread }(1) ; \\ \phi, & \text { rim angle (1); } \\ \eta, & \text { collector efficiency (1); } \\ \eta_{0}, & \text { optical efficiency }(1) ; \\ \eta_{\mathrm{E}}, & \text { thermal transport efficiency }(1) ; \\ \eta_{\mathrm{F}}, & \text { thermal conversion efficiency (conventional } \\ \theta, & \text { system) (1); } \\ \rho_{\mathrm{m}}, & \text { mirror reflectance }(1) .\end{array}$

\section{INTRODUCTION}

THE CONCENTRATION of solar radiation by reflection (mirrors) or refraction (lenses) on the receiver of a thermal conversion system, has the distinct thermodynamic advantage of reducing the thermal losses in the conversion process in relation to the useful thermal gain in comparison with non-concentrating systems (flat plate collectors). This results in an increased thermal conversion efficiency for a specified set of operating conditions and allows for the production of higher operating temperatures at acceptable conversion efficiencies. An increased conversion efficiency improves the economic performance of the system and higher operating temperatures (in comparison with those obtained by flat plate collectors) allows concentrating systems to be used in a wide variety of industrial process heat applications. Concentrating collectors include the compound parabolic concentrator (CPC) with a concentration ratio (CR) range 210 , the parabolic trough concentrator (CR from $10-100)$ and the parabolic dish concentrator (CR from 100-3000). The heliostat mirror system of the central tower receiver is, in principle, a special form of parabolic dish. Apart from the CPC, which can accept diffuse radiation, a concentrating collector can utilize only the direct, or beam, component of solar radiation and is arranged such that its aperture is facing in the direction of the sun as closely as possible, i.e. it tracks the sun. On a clear day the beam component repre- sents $80-90 \%$ of the total solar radiation. The actual concentration of solar radiation is limited in a given system by the dispersion of the radiation created by the finite size of the solar disc. At the mean sun earth distance, the sun subtends an angle of $9 \mathrm{mrad}$, thus fixing a lower limit to the size of the receiver and an upper limit on the concentration ratio. Other practical considerations such as reflector uniformity, receiver misalignment, tracking errors and optical end losses further limit the degree of concentration that is possible.

The market potential for industrial application of solar concentrators (thermal and photovoltaic) is considerable. In the United States approximately $20 \%$ of the total thermal energy useage is in the range of temperatures $100-300^{\circ} \mathrm{C}(212-572 \mathrm{~F})$. In 1980 this represented an energy consumption of about 16 quads $\left(16 \times 10^{15} \mathrm{~B} T \mathrm{U}\right)$. To provide for this using solar concentrators would require a total aperature area of approximately $48 \times 10^{9} \mathrm{ft}^{2}\left(4.5 \times 10^{9} \mathrm{~m}^{2}\right)$. At the present time the total installed area of concentrators is less than $10^{6} \mathrm{ft}^{2}\left(93 \times 10^{3} \mathrm{~m}^{2}\right)$. Hence, the challenge and opportunity for this type of solar application is evident. The purpose of this paper is to discuss some of the important design parameters and present an economic projection for parabolic trough concentrators in the United States. The results can be extended to other regions of the world. A recent summary of this technology, including high temperature storage, has been published by Kreith, Castle and Wyman [1]. The SANDIA laboratories at Albuquerque, New Mexico, have done extensive work on the development of engineering prototype parabolic troughs. A detailed analysis of the manufacturing costs of a parabolic trough concentrator for both high and low volume production has been completed [2].

A photograph of a typical parabolic trough concentrator is shown in Fig. 1 and its application to an industrial process, with the associated auxiliary equipment and conventional supply system is shown in Fig. 2.

DESIGN AND MANUFACTURING PARAMETERS THAT INFLUENCE THERMAL AND ECONOMIC PERFORMANCE

The economic performance of a parabolic trough concentrator is directly related to its annual thermal performance. The thermal performance, measured in terms of the quantity of useful energy obtained annually from the concentrator by solar conversion, is in turn determined by certain critical design parameters and manufacturing process selections. Accordingly, for a comprehensive design study to be conducted and an effective manufacturing system to be identified, it is essential that an understanding be obtained regarding these design parameters and their influence on the thermal performance, and, ultimately the economic performance of the concentrator. The following development will be a summary of the principal results of 


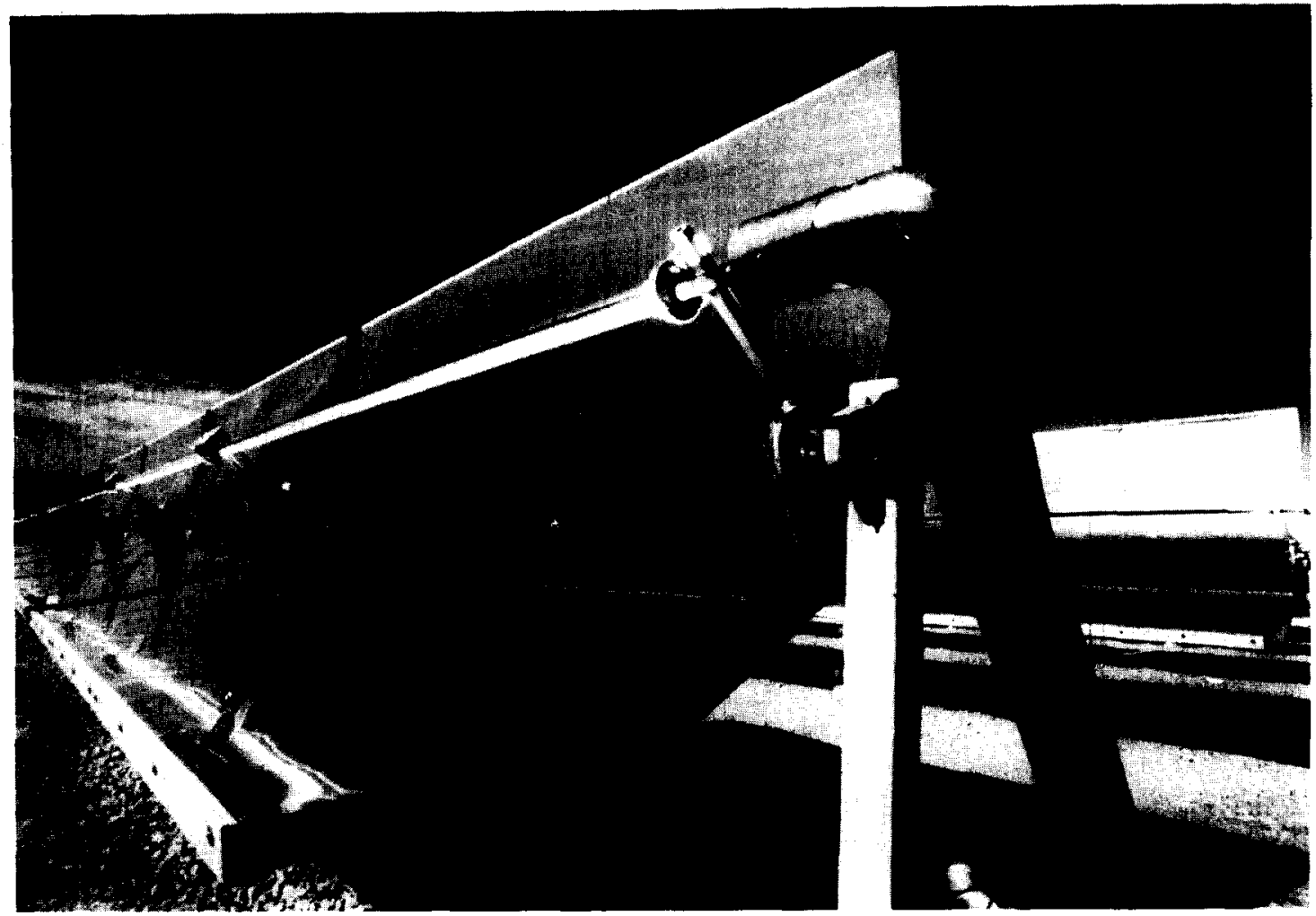

FIG. 1. Parabolic trough concentrator (courtesy Acurex Corporation).

a thermal analysis which identifies the important design parameters.

\section{Thermal efficiency of a concentrator}

As a figure of merit, the thermal efficiency of a concentrator is defined as follows:

$$
\eta \equiv \frac{\text { Useful energy produced }}{\text { Energy incident on collector aperture }}
$$

or

$$
\eta \equiv \frac{q_{\mathrm{u}}}{q_{x}},
$$

where the useful energy $q_{\mathrm{u}}$ is the difference between the energy absorbed at the receiver tube, $q_{\mathrm{A}}$, and the energy loss at the receiver, $q_{0}$. Hence,

$$
q_{\mathrm{u}}=q_{\mathrm{A}}-q_{0}
$$

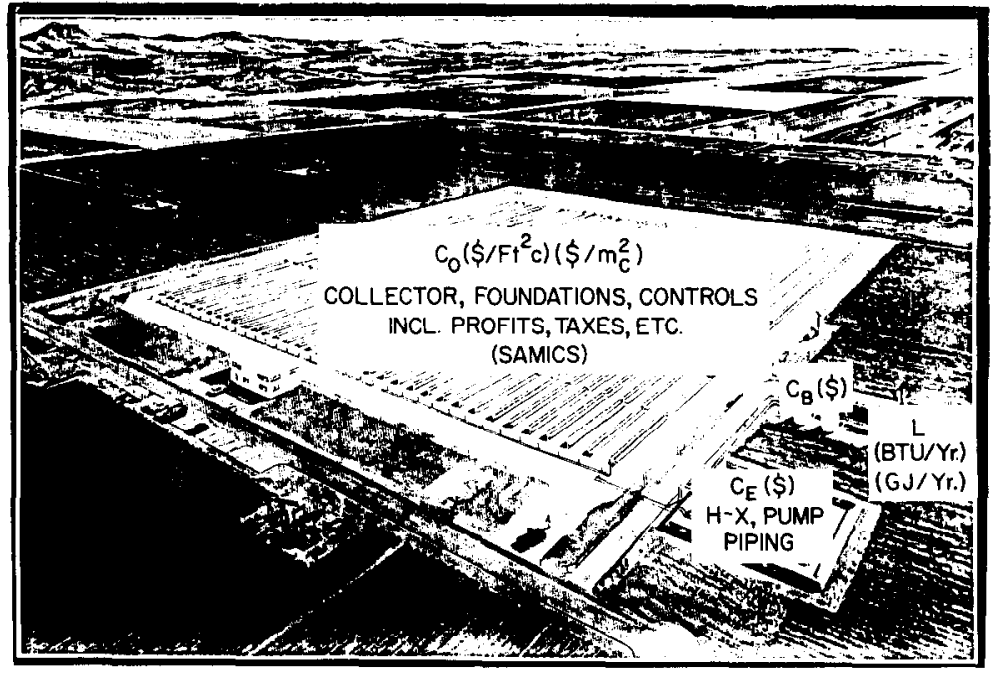

FIG. 2. Parabolic trough field for industrial process heat application (courtesy Acurex Corporation). 
also

$$
q_{\propto}=I_{\mathrm{DN}} A_{\mathrm{c}} \cos \theta=I_{\mathrm{DS}} A_{\mathrm{C}}
$$

and

$$
\begin{aligned}
& q_{\mathrm{A}}=F_{\mathrm{R}} q_{x} \eta_{0}, \\
& q_{0}=F_{\mathrm{R}} U_{0} A_{0}\left(T_{\mathrm{i}}-T_{\mathrm{a}}\right),
\end{aligned}
$$

thus,

$$
\eta=F_{\mathbf{R}}\left[\eta_{0}-\frac{U_{0}}{\left(A_{\mathrm{c}} / A_{0}\right)} \frac{\left(T_{\mathrm{i}}-T_{\mathrm{a}}\right)}{I_{\mathrm{DS}}}\right]
$$

As a practical matter for large coolant flows, $F_{\mathrm{R}}$ will be in the range 0.8-0.9. However, the actual value for $F_{\mathrm{R}}$ in a given design will depend on $D_{0}$, the choice of which is a trade-off between minimizing thermal losses from the receiver (proportional to $D_{0}$ ) and maximizing the interception of reffected radiation from the mirror by the receiver tube. These processes are influenced by the receiver-tube-mirror intercept factor, which is discussed below in connection with the optical efficiency $\eta_{0}$ of the system.

The optical efficiency $\eta_{0}$ is a principal design parameter whose magnitude is determined by the values of six other independent parameters. This quantity is written [4]

$$
\begin{aligned}
\eta_{0}=\rho_{\mathrm{m}}(\theta) F_{\mathrm{m}}\left(\psi_{1}, \psi_{2},\right. & \left.A_{\mathrm{c}}, \phi\right) K_{0}(\theta) \\
& \times(\alpha t)_{0} F_{\mathrm{E}}(f, L, 0, W) F_{\mathrm{T}}\left(\theta_{\mathrm{t}}\right) .
\end{aligned}
$$

Each of the six parameters $\rho_{\mathrm{m}}, F_{\mathrm{m}}, K_{0},(\alpha \tau)_{0}, F_{\mathrm{E}}$ and $F_{\mathrm{T}}$ will be discussed and their significance to design and manufacturing will be presented.

The mirror reflectivity, $\rho_{\mathrm{m}}(\theta)$. The reflectivity of the mirror, $\rho_{m}(\theta)$, is the fraction of the incident radiation that is reflected from the mirror system. The magnitude of $\rho_{\mathrm{m}}(\theta)$ will depend on the nature of the mirror system, that is, whether it consists of glass with a reflective metal coating on the second surface, an acrylic coated film, a polished metal surface, etc. In the case of a glass, second surface mirror reflector $\rho_{\mathrm{m}}(\theta)$ will be influenced by reflection from both the air-glass interface and the glass-metal interface as well as by optical absorption within the glass. Because absorption is the consequence of two light passes through the glass and the optical absorptivity of the glass, the mirror system should be constructed of glass that is thin as possible $(0.040-0.200$ in $)$ and that contains very small quantities of iron, the principal impurity causing absorption. The reflectivity of the metal surface that forms the mirror should be as high as possible, approx. $0.90-0.95$.

The magnitude of the reflectivity is also a function of the angle of incidence $\theta$ on the mirror surface and the angle of reflection. In general, an ideal situation is one in which the angle of incidence and angle of reflection on the mirror are the same. However, owing to the finite size of the sun, which causes a spread in the incident radiation, and both gcometric and optical imperfections in the mirror system there will always be some dispersion of the reflected beam from the re- flector. Material selection of the mirror system and the precision of its manufacture should be such as to minimize this beam dispersion.

Mirror-receiver tube intercept factor, $F_{\mathrm{m}}\left(\psi_{1}, \psi_{2}, A_{c}\right.$, $\phi)$. Because the sun has finite size, its incident radiation of the collector aperture possesses a small (approx. $9 \mathrm{mrad}$ ) conical beam spread of angle $2 \psi_{2}$. Further, the mirror surface itself will have a local surface curvature different from that of a perfect parabola of revolution. This is a consequence of imperfections in the manufacturing process which produce what are known as slope errors in the parabolic surface. Such errors must be made small and for a particular design should be known. The effect of both solar beam spread and mirror slope errors is to cause an additional dispersion in the reflected beam. Hence, at the receiver tube the reflected energy is spread over a finite angle rather than focused along a line as would be obtained from a point source reflecting from a perfect parabolic trough. The solar beam spread $2 \psi_{2}$ is predictable and can be described in terms of a statistical variance (square of the standard deviation of the distribution of the beam spread), defined as $\sigma_{\psi_{2}}^{2}$. The effect of mirror surface slope errors, however, is not predictable but must be determined from measurements on an actual surface. One technique is to use a highly collimated laser beam that scans the mirror and measures the deflection angle $\psi_{1}$ of the reflected beam from the focal line of the mirror. Treadwell [3] describes this method and gives a typical scan which is shown in Fig. 3. The effect of these surface imperfections is also described in terms of a statistical variance of the deviations of the surface from that a perfect parabola, defined here as $4 \sigma_{* \psi_{1}}^{2}$. Employing a principle of statistics which asserts that the variance of a system of random variables is the sum of the variances of each variable, the net variance of the solar beam spread and mirror slope errors is written as

$$
\sigma_{\theta}^{2}=4 \sigma_{\psi_{1}}^{2}+\sigma_{\psi_{2}}^{2} .
$$

Further, the beam spread variance at the receiver, $\sigma_{v}^{2}$, of the entire collector surface is obtained by integrating these effects over the complete rim angle (2) of the concentrator trough (4). Thus, for an aperture of width $w$,

$$
\sigma_{y}^{2}=\frac{w^{2} \sigma_{0}^{2}(2+\cos \phi)}{12 \phi \sin \phi}
$$

The solar beam spread standard deviation is $2.5 \mathrm{mrad}$ and the slope error standard deviation $\sigma_{\psi_{1}}$ should be such that the beam spread standard deviation $\sigma_{y}$ is less than $7 \mathrm{mrad}$ for a parabolic trough concentrator of high quality.

These effects are fundamental to the selection of the size of the receiver tube. The larger the tube diameter, the more reflected radiation it will intercept. However, as the tube diameter is increased the thermal losses will also increase. The final selection of tube diametcr is then made on the basis of a trade-off between increased interception of reflected radiation and acceptably 


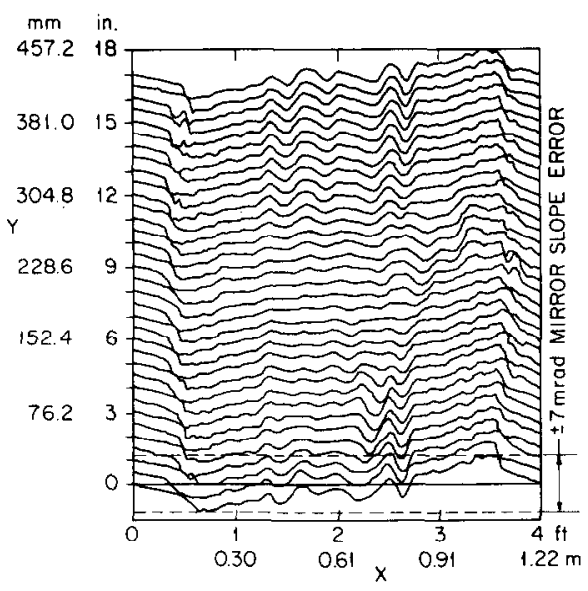

FIG. 3. Laser scan of parabolic trough mirror [3].

small thermal losses. An example of such a design selection made by the Sandia National Laboratories [3] is given in Fig. 4. The actual determination of tube size is made by statistical analysis, assuming the random distribution of these effects is Gaussian (normal). This assumption leads to the formulation of the mirror-receiver tube intercept factor as follows [4]:

$$
F_{\mathrm{m}}\left(\psi_{1}, \psi_{2}, A_{\mathrm{c}}, \phi\right)=\frac{1}{(2 \pi)^{1 / 2}} \int_{-a}^{+a} \mathrm{e}^{-z^{2} / 2} \mathrm{~d} z
$$

where

$$
z \equiv \frac{y}{\sigma_{y}}, \quad a \equiv \frac{D_{0} / 2}{\sigma_{y}}
$$

$y$, being the radial spread coordinate of the reflected and dispersed beam across the focal line of the receiver tube $\left(0 \leqslant y \leqslant D_{0} / 2\right)$.

Also, as may be shown from the properties of a Gaussian distribution,

$$
F_{\mathrm{m}}\left(\psi_{1}, \psi_{2}, A_{\mathrm{c}}, \phi\right)=2 F(a)-1,
$$

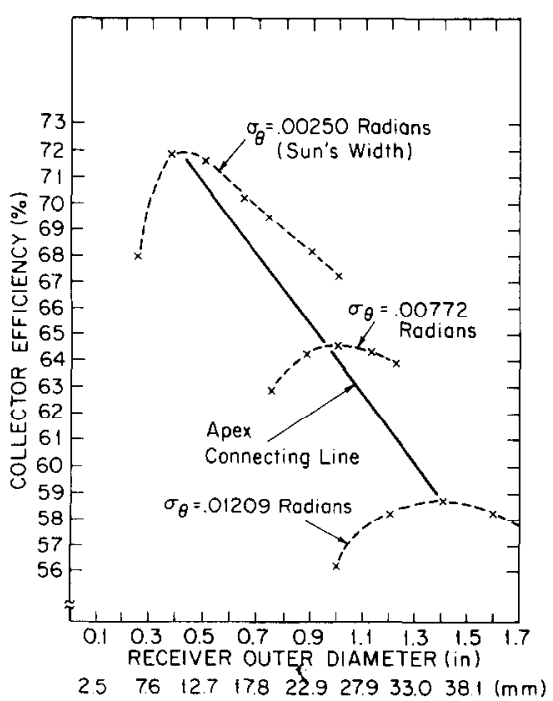

FIG. 4. Energy distribution vs collector efficiency [3] where $F(a)$ is the normal distribution function,

$$
F(a)=\frac{1}{(2 \pi)^{1 / 2}} \int_{-\infty}^{a} \mathrm{e}^{-z^{2} / 2} \mathrm{~d} z .
$$

Numerical values for $F(a)$ may be found in mathematical handbooks [5]. These results are employed in one of two ways. First, the fraction of the intercepted radiation $\left(F_{\mathrm{m}}\right)$ that is desired (range $\left.0.90-0.95\right)$ is specified and the corresponding receiver tube diameter that would produce this for the conditions of the mirror-sun $\left(\sigma_{y}\right)$ and concentrator geometry is determined. The second way is the inverse of the first. Namely, specifying the tube diameter and from the conditions of the mirror-sun $\left(\sigma_{y}\right)$ and the concentrator geometry a determination of $a$, and thus $F(a)$ is made. The intercept $F_{\mathrm{m}}\left(\psi_{1}, \psi_{2}, A_{\mathrm{c}}, \phi\right)$ then follows from equation (14). In this case the value of $a$ for the determination of $F(a)$ is $\left(D_{0} / 2\right) / \sigma_{y}$

$K_{0}(\theta)$, incident angle modifier and $(\alpha \tau)_{0}$, the absorptivity-transmissivity product at normal incidence of the receiver tube and its glass envelope. From a thermal optical analysis it is found that the net energy absorbed by the receiver tube is proportional to the product of the optical transmissivity, $\tau$, of the glass cover tube over the receiver and the absorptivity of the receiver tube, both within the spectrum of the sun $(0.3-2.5 \mu \mathrm{m})$. Owing to the physics of the interaction of radiation and solid media, each of these properties ( $\tau$ and $\alpha$ ) is dependent on the angle of incidence $(\theta)$ of the radiation with the surfaces of the medium. An additional factor is the absorption of radiation within the media, which in this case, is absorption within the glass cover tube. This should be small, a condition obtained by using a thin-walled tube of low iron glass. Both $\tau$ and $\alpha$ should be as large as practical, though neither can exceed 1.0 .

To account for the influence of various incident angles on $(\alpha \tau)$, a factor known as the incident angle modifier, called $K_{0}(\theta)$ is determined. The value of $(\alpha \tau)$ for any angle of incidence, $\theta$, is obtained by the product of $K_{0}(\theta)$ and the value of $(\alpha \tau)_{0}$ corresponding to radiation incident in a direction normal to the surface. Each of thesc factors can be determined using physicaloptical theory or they can be measured experimentally. Typical values for $\tau, \alpha$ and $K_{0}$, each as a function of the incident angle, are given in Figs. 5 and 6.

End loss factor, $F_{\mathrm{E}}(f, L, w, \theta)$. By the nature of its design a parabolic trough concentrator has open ends. Because of this a certain amount of radiation incident on the aperture does not reflect from the mirror and intercept the receiver tube. To account for this effect, an end loss factor is introduced, which is given [6] as

$$
F_{\mathrm{E}}(f, L, w, \theta)=1-\frac{f}{L}\left[1-\frac{(w / f)^{2}}{48}\right] \tan \theta .
$$

A collector that is long in relation to its focal length has small end loss, as is the case when energy falls on the aperture at normal incidence.

$F_{\mathrm{T}}\left(\theta_{\mathrm{t}}\right)$, tracking and receiver misalignment error. The 


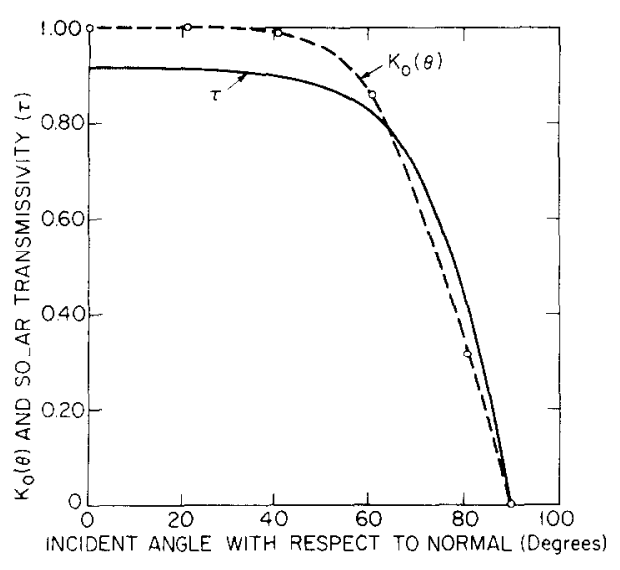

FIG. 5. Solar transmissivity and incident angle modifier of receiver tube glass envelope [14].

last of the six factors that are important to design and manufacturing considerations and which influence the thermal performance of a concentrator is the tracking and receiver misalignment error. This error results, in general, whenever the receiver tube is displaced from the designed region of focus. Two common causes for this error in displacement are errors in the tracking mechanism, and manufacturing and/or operational misalignment of the receiver tube resulting from sagging or thermal distortion. Of these the tracking error is the more important as manufacturing and assembly tolerances can be realistically maintained to values well within those demanded for thermal performance. In current designs 'stacking' errors of 0.200 in $(0.508 \mathrm{~cm})$ are allowed, whereas manufacturing and assembling tolerances can be realistically specified that produce 'stacking' errors of about 0.050 in $(0.127 \mathrm{~cm})$. The importance of precise tracking capability is shown in Fig. 7 where, for the concentrator shown [7], a $1^{\circ}$ tracking error produces a $20 \%$ reduction in the efticiency. The actual tracking error will depend on the system geometry but generally the requirements for precision in tracking will be great, within one or two degrees.

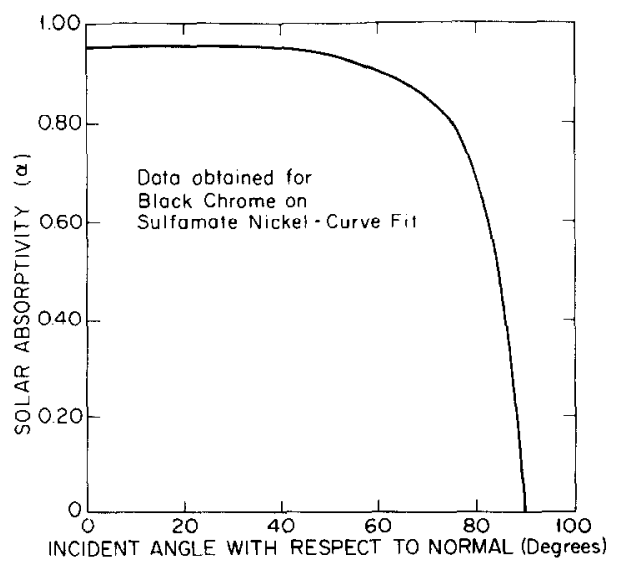

Flg. 6. Solar absorptivity of receiver tube [14].
Other design considerations. While the discussion above has been directed at important design/manufacturing parameters there are others that should be mentioned briefly. The thermal loss from the receiver tube should be made as small as is practical. Considerations bearing on this include a low emissivity (at infra-red wave lengths) of the absorber surface and protection of this surface from convection losses. The latter is accomplished by placing a glass tube around the receiver tube. Evacuating the space between the two tubes and coating the glass tube with an antireflection coating can act to reduce thermal losses significantly. Anti-reflection coating of the receiver tube, for example, can be expected to improve the collector efficiency by approximately $5 \%$, making this a highly cost-effective step. To date evacuation of the annulus has not proven satisfactory in field operations.

Finally, the lifetime performance of the various materials used in any particular collector must be taken into account. Durability of the reflector surface is a major factor in this regard, and militates strongly against the use of reflecting surfaces whose performance degrades substantially with time in an open environment or is damaged by a cleaning process.

\section{Energy cost analysis}

The utilization of parabolic trough concentrators in the conservation of solar energy for use in industrial processes depends primarily on the economics and costs of the application. The durability, reliability and maintainability of materials, components and systems also are important to the adoption of this technology. However, for industry to utilize this technology it must be expected that these solar systems be capable of producing useful energy at costs below that for competing energy sources. In this section the cconomics and costs of the parabolic trough concentrator are analyzed in terms of the appropriate financial, physical and production cost parameters.

These parameters include tax incentives, tax credits, cost of conventional (competing) fuel, cost of capital, cost of ownership (taxes), rate of inflation, rate of fuel cost escalation, type of capital borrowing, period of time of borrowing and the discount rate on capital, maintenance costs, total installed costs of the con-

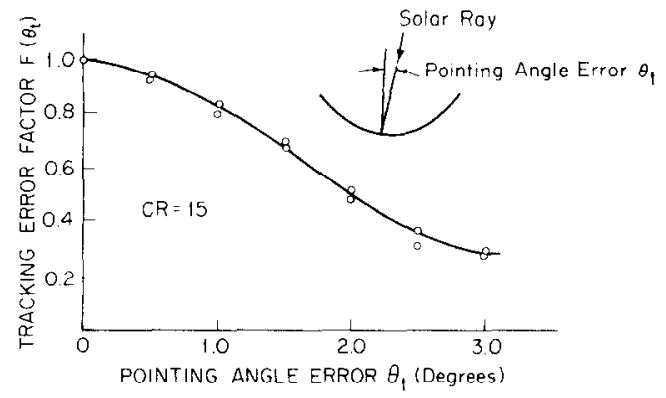

FIG. 7. Tracking accuracy factor as a function of pointing angle error [7]. 
centrator, including all manufacturing and materials costs, profit and taxes, cost of auxiliary equipment such as heat exchangers, pumps, piping and controls, the conversion efficiencies of collector conventional boiler and energy transmission system, and the geographic location. The cost analysis made here includes an evaluation of the total costs over an investment period (life-cycle analysis) as well as the annual cash flow during this period. Each of these representations has its value in the economic evaluation of the concentrator for industrial process heat application.

The technical performance characteristics of the concentrator are taken from the work of the Sandia National Laboratories, the Component and Subsystem Development Division, the Small Power Systems Applications Division and the Experimental Systems Operations Division (8). Although the analysis developed here is general, the results will be applied to the newer designs of parabolic trough concentrators developed in prototype models at Sandia which have significantly improved performance over current production models. It is anticipated these improved prototypes can be manufactured in volume production during the 1980s. The improvements in the design include improved reflectivity of the mirror, more precise mirror shape (small errors in slope), better beam focusing and reduced thermal losses from the receiver. Both north-south and east-west axes (horizontal) orientation, with tracking, can be considered. Results for three more or less representative U.S. locations are given: Albuquerque, New Mexico, Fresno, California and Caribou, Maine. These results are for an east-west orientation and can be modified for north-south orientation with a corresponding $10-20 \%$ improvement in performance [8].

The collector configuration used for these economic calculations is a Sandia design having an aperture $6.56 \mathrm{ft}$ wide $(2.0 \mathrm{~m}), 103 \mathrm{ft}$ long $(31.39 \mathrm{~m})$ with a $90^{\circ}$ rim angle. The inlet temperature is $500^{\circ} \mathrm{F}\left(260^{\circ} \mathrm{C}\right)$ and an outlet temperature of approximately $600^{\circ} \mathrm{F}\left(316^{\circ} \mathrm{C}\right)$. The receiver tube has a selective coating and is surrounded by a Pyrex glass tube without evacuation. An anti-reflection coating on the glass cover tube is not included but such a coating would improve the performance by $5-10 \%$. Evacuation also improves performance but has not proved to be practical in field testing. The effect of shadowing is also not included but this loss can be expected to be compensated by the improvement in performance obtained by the use of anti-reflection coating in future designs. The receiver tube diameter is selected to optimize the performance by minimizing thermal losses while maximimizing beam interception. The exact diameter will vary slightly with location but will be in the range of 1.0-1.5 in $(2.54-3.81 \mathrm{~cm})$. The optimum performance is not particularly sensitive to small variations in diameter.

Long term averaged solar and weather data are used to determine the technical performance. The Sandia results cited here have used the Typical Meteorological Year (TMY) data generated by Sandia.

\section{Economic analysis}

The collector field, auxiliary equipment, conventional thermal supply system is shown in Fig. 2. The collector field is described by its total area of aperture, $A_{\mathrm{c}}$, and its total installed cost per unit of aperture area, $C_{0}$, in dollars per square foot $\left(\$ \mathrm{~m}_{\mathrm{c}}^{-2}\right)$. This cost is determined by a detailed analysis of the materials and manufacturing costs associated with production of the concentrator for various annual volumes of manufacture [2]. These costs include the costs for foundations, controls, profits, taxes, etc., the details of which and the methodology of assessment are given in [2].

Associated with the collector field is a thermal energy conversion sub-system consisting of pumps, valves, heat exchanger and related structure which is represented in the economic analysis by the $\operatorname{cost} C_{\mathrm{E}}$, in $\$$. This cost will vary depending on the specific choices made regarding the total system and its application. For purposes of the present analysis this cost will be related to the total collector aperture area as the quantity $C_{\mathrm{E}} / A_{\mathrm{c}}$, in dollars per unit area of aperture. Studies [2] have indicated that a value of $C_{\mathrm{E}} / A_{\mathrm{c}}$ equal to $\$ 2.79 \mathrm{ft}_{\mathrm{c}}^{-2}\left(\$ 30.03 \mathrm{~m}^{-2}\right)$ would be an appropriate figure. However, other values can be introduced for different situations.

Also indicated on Fig. 2 is the cost $C_{\mathrm{B}}$, dollars, for the conventional boiler and the total thermal load, $L$, BTU $\mathrm{yr}^{-1}\left(\mathrm{GJ} \mathrm{yr}^{-1}\right)$, of the combined solar-conventionally fueled plant. Because of the nature of the economic analysis, the cost of the conventional boiler, $C_{\mathrm{B}}$, does not enter explicitly into the economic determinations.

An economic assessment of the parabolic trough concentrator as an energy supply system is made by determining the difference in cost over some period of time between that of a conventional energy supply system and that of the solar concentrator system including its auxiliary equipment and back-up conventional boiler. Hence,

$$
\Delta C=C_{\mathrm{c}}-C_{\mathrm{sc}} .
$$

where

$$
\begin{aligned}
C_{\mathrm{c}} & =\text { Cost of conventional system }(\$), \\
C_{\mathrm{sc}} & =\text { Cost of solar-auxiliary system }(\$) .
\end{aligned}
$$

Economic viability for the solar system occurs whenever

$$
\Delta C \geqslant 0,
$$

and economic 'breakeven' occurs when

$$
\Delta C=0 .
$$

Considering capital costs, taxes, fuel costs and maintenance costs, $\Delta C$ is written

$$
\begin{aligned}
\Delta C=- & \left(A_{\mathrm{c}} C_{0}^{\prime}+C_{\mathrm{e}}^{\prime}\right)\left(I_{0}^{\prime}+T_{0}^{\prime}\right) F_{1}(x, t) t \\
& +F_{\mathrm{s}} L \frac{C_{\mathrm{F}_{0}}^{\prime}}{\eta_{\mathrm{F}}} F_{1}(a, t) t-M_{\mathrm{sco}}^{\prime} F_{1}(i, t) t,
\end{aligned}
$$

where the primed notation represents effective costs, to 
include the effects of certain tax and investment credits. The function $F_{1}(x, t)$ is an escalation function [9] that allows for increases in costs as a result of general inflation $(x=i)$, fuel price escalation $(x=a)$ and variable rate borrowing $(x=v)$ and is given in Table 1 . Subscripts 0 refers to current costs or price levels. Accordingly, it may be shown that the product of the current cost (or price) and the function $F_{1}(x, t)$ is the exact mean value of the cost (or, price) of the commodity or service over the period of time $t$. Hence, equation (19) is an expression of life-cycle costs written in terms of exact mean values and indexed on the current (thus, known) values with consideration of an assumed rate of increase $(x, a, i)$ over the period $t$. This formulation is a valid representation of the economic performance for a long term investment in which the cost elements increase according to $(l+x)^{t}$.

In the following development these various costs are assumed to have the escalation rates listed:

(i) current capital cost, $I_{0}^{*}$, increases at rate, $x=v$. $(v=0$ for fixed rate borrowing, the case actually developed here) (ii) current tax rate, $T_{0}^{\prime}$, increases at general inflation rate, $x=i$.

(iii) current fuel price $C_{F_{0}}^{\prime}$ (at meter), increases at the fuel escalation rate, $x=a$, where $a>i,(a \quad i=0.05$ in this study)

(iv) maintenance costs, $M_{\mathrm{sco}}^{\prime}$ increase at general inflation rate, $x=i$.

The solar system maintenance costs are taken to be proportional to the total plant investment, including auxiliary equipment. Hence,

$$
M_{\mathrm{sco}}^{\prime}-K_{0}^{\prime} C_{0}^{\prime}\left(1+C_{\mathrm{E}}^{\prime} / C_{0}^{\prime} A_{\mathrm{c}}\right) A_{\mathrm{c}} .
$$

Noting that $F_{s} L$ is the annual quantity of useful energy provided by the solar system, this may be written as

$$
F_{\mathrm{s}} L=\eta_{\mathrm{c}}\left(Q_{\mathrm{s}} / A_{\mathrm{c}}\right) A_{\mathrm{c}} .
$$

With these formulations equation (19) may be written in dimensionless form as

$$
\begin{gathered}
\frac{(\Delta C / t) / C_{\mathrm{F}_{0}}}{\left(\eta_{\mathrm{E}} / \eta_{\mathrm{F}}\right) A_{\mathrm{c}}\left(Q_{\mathrm{s}} / A_{\mathrm{c}}\right)\left(1-C_{\mathrm{s}}\right) F_{\mathrm{t}}(a, t)}=1 \\
\left(1-C_{\mathrm{i}}-C_{\mathrm{T}}\right) C_{0}\left(1+C_{\mathrm{E}} / C_{0} A_{\mathrm{c}}\right) F_{1}(i, t) \\
\left(\eta_{\mathrm{E}} / \eta_{\mathrm{F}}\right)\left(1-C_{\mathrm{s}}\right)\left(Q_{\mathrm{s}} / A_{\mathrm{c}}\right) C_{F_{0}} F_{1}(a, t)
\end{gathered}
$$

Table 1. $F_{1}(x, t)$

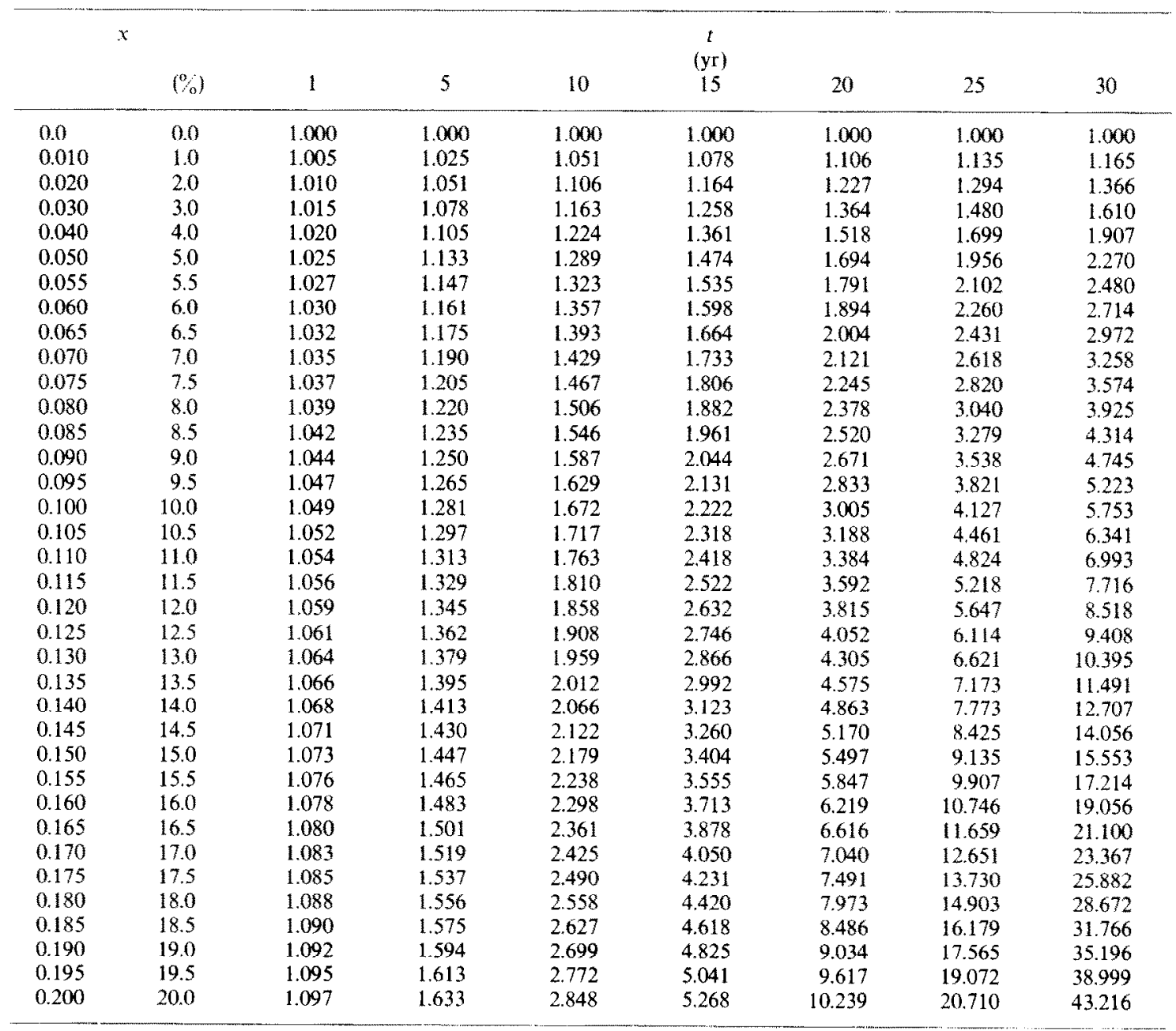




$$
\times\left[\left(T_{0}+K_{0}\right)\left(1-C_{\mathrm{s}}\right)+I_{0} R_{\mathrm{s}} \frac{F_{1}(v, t)}{F_{1}(i, t)}\right] .
$$

The function $F_{1}(x, t)$ is given in Table 1 for values of $x$ from $0 \% \mathrm{yr}^{-1}$ to $20 \% \mathrm{yr}^{-1}$ and time periods of $1-30$ yr. These ranges should accommodate most practical circumstances.

The economic performance of the parabolic trough concentrator can be determined using equation (22) and its analytical sub-structure to calculate the following economic/cost conditions:

(i) Total return on investment $\mathrm{ft}^{2}$ of collector aperture area, $\Delta C / A_{\mathrm{c}}\left(\$ \mathrm{ft}_{\mathrm{c}}^{-2}, \$ \mathrm{~m}^{-2}\right)$, for various periods of investment.

(ii) Breakeven current metered fuel cost, $\left(C_{F_{0}}\right)_{\min }$, $\left(\$ 10^{-6} \mathrm{BTU}, \$ \mathrm{GJ}^{-1}\right)$ for various total installed collector costs, $C_{0}$, and various periods of investment. (Values of $\left(C_{F_{0}}\right)_{\min }$ for $C_{0}$ of $\$ 13.00 \mathrm{ft}_{\mathrm{c}}\left(\$ 140 \mathrm{~m}^{-2}\right)$ and $\$ 20.00 \mathrm{ft}_{\mathrm{c}}^{-2}\left(\$ 215.00 \mathrm{~m}^{-2}\right)$ for periods of investment ranging from 5 to $15 \mathrm{yr}$ at Albuquerque, New Mexico, Fresno, California and Caribou, Maine are given in Figs. 8 and 9.)

(iii) Annual cash flow at both breakeven conditions and positive net return on investment considering the costs of ownership of the solar system and value of fuel displaced. (Results of these determinations for a total period of investment of $15 \mathrm{yr}$ and for total installed collector cost of $\$ 19.54 \mathrm{ft}_{\mathrm{c}}^{-2}\left(\$ 210.00 \mathrm{~m}^{-2}\right)$ and $\$ 9.91$ $\mathrm{ft}_{\mathrm{c}}^{-2}\left(\$ 107.00 \mathrm{~m}^{-2}\right)$ each for $C_{F_{0}}$ of $\$ 3.36 / 10^{6} \mathrm{BTU}^{-1}$ are given in Figs. 10 and 11 for Abuquerque, New Mexico insolation.)

All economic results are determined for a common set of economic parameters which are taken to be representative of economic conditions and in accord with tax provisions in effect in the United States in 1982. Other conditions may be used for other situations as conditions may change.

The economic parameters are as follows:

$$
\begin{array}{rlrl}
C_{\mathrm{i}} & =0.10(10 \%) & K_{0} & =0.02 \mathrm{yr}^{-1}\left(2 \% \mathrm{yr}^{-1}\right) \\
C_{\mathrm{T}} & =0.15(15 \%) & T_{0} & =0.02 \mathrm{yr}^{-1}\left(2 \% \mathrm{yr}^{-1}\right) \\
C_{\mathrm{S}} & =0.50(50 \%) & i & =0.10 \mathrm{yr}^{-1}\left(10 \% \mathrm{yr}^{-1}\right) \\
\eta_{\mathrm{E}} & =0.95(95 \%) & a & =0.15 \mathrm{yr}^{-1}\left(15 \% \mathrm{yr}^{-1}\right) \\
C_{\mathrm{E}} / A_{\mathrm{c}} & =\$ 2.79 / \mathrm{ft}_{\mathrm{c}}^{2} & v & =0.00 \mathrm{yr}^{-1}\left(0 \% \mathrm{yr}^{-1}\right) \\
Q_{\mathrm{s}} / A_{\mathrm{c}} & =\mathrm{BTU} \mathrm{ft}_{\mathrm{c}}^{-2} \mathrm{yr}^{-1}: \text { Annual useful energy } \\
\text { produced by the trough }(8) &
\end{array}
$$

$$
\begin{aligned}
\text { Albuquerque, New Mexico } & : 406000 \mathrm{BTU} \mathrm{ft}_{\mathrm{c}}^{-2} \mathrm{yr}^{-1}\left(1280 \mathrm{kWh} \mathrm{m}^{-2} \mathrm{yr}^{-1}\right) \\
\text { Fresno, California } & : 340000 \mathrm{BTU} \mathrm{ft}^{-2} \mathrm{yr}^{-1}\left(1072 \mathrm{kWh} \mathrm{m}^{-2} \mathrm{yr}^{-1}\right) \\
\text { Caribou, Maine } & : 175000 \mathrm{BTU} \mathrm{ft}_{\mathrm{c}}^{-2} \mathrm{yr}^{-1}\left(552 \mathrm{kWh} \mathrm{m}^{-2} \mathrm{yr}^{-1}\right)
\end{aligned}
$$

The useful energy obtained annually per $\mathrm{ft}^{2}$ of collector aperture, $Q_{\mathrm{s}} / A_{\mathrm{c}}$, was also determined on the basis of current trough technology for Albuquerque, New Mexico, using a clear-sky solar irradiation model modified for sunshine fraction. A quantity of 271, $182 \mathrm{BTU} \mathrm{ft}^{-2} \mathrm{yr}^{-1}\left(855 \mathrm{kWh} \mathrm{m}^{-2} \mathrm{yr}^{-1}\right)$ was com-

$\eta_{\mathrm{F}}=0.60$

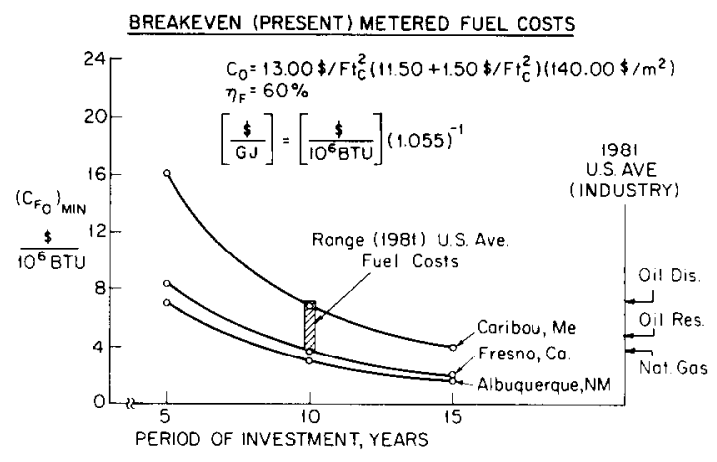

FIG. 8. Breakeven (present) metered fuel costs for $C_{0}=$ $\$ 13.00 \mathrm{ft}_{\mathrm{c}}^{-2}\left(\$ 140.00 \mathrm{~m}^{-2}\right)$.

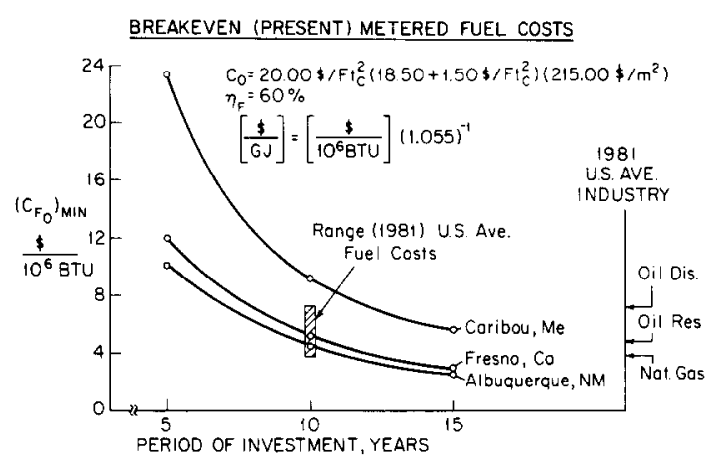

FIG. 9. Breakeven (present) metered fuel costs for $C_{0}=$ $\$ 20.00 \mathrm{ft}_{\mathrm{c}}^{-2}\left(\$ 215.00 \mathrm{~m}^{-2}\right)$.

puted for an $\mathbf{E}-\mathbf{W}$ axis orientation. This result compared within $8 \%$ of that determined by the Sandia National Laboratories for four current U.S. designs of parabolic trough concentrators $[11,12]$. However, in view of the fact that future trough designs will have improved performance and that all costs determined in this study are for production systems that also are expected to be produced by future manufacturing

$i d=0.13 \mathrm{yr}^{-1}$

$$
\left(13 \% \mathrm{yr}^{-1}\right)
$$

$t=5,10,15 \mathrm{yr}$

systems, it was decided that the more realistic and consistent approach would be to use the future expected values for both costs and thermal performance in an economic analysis. For this reason the values of $Q_{\mathrm{s}} / A_{\mathrm{c}}$ listed above correspond to the performance of troughs presently in an engineering pro- 


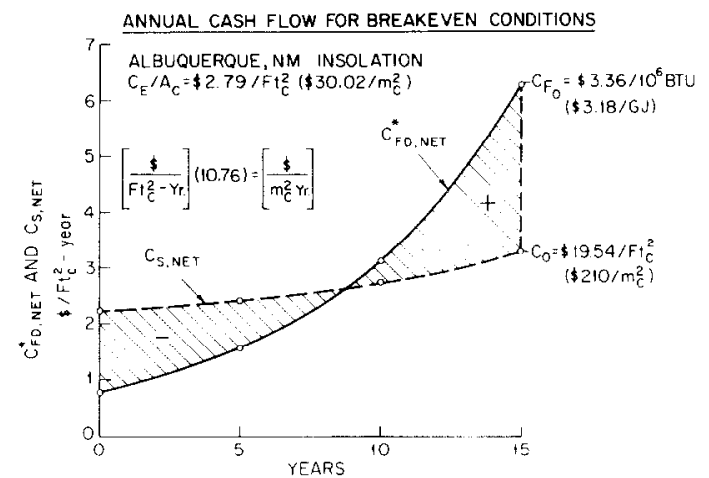

Fig. 10. Annual cash flow for breakdown conditions. Albuquerque, New Mexico insolation.

totype state of development but which are expected to be produced in future volume production.

Total return on investment, $\Delta C / A_{\mathrm{c}}$. The total return on investment per $\mathrm{ft}^{2}\left(\mathrm{~m}_{\mathrm{c}}^{2}\right)$ of collector is that value of $\Delta C / A_{c}$ from equation (25) computed for various economic, geographic and technical conditions that may he given. Because of space limitations results of this determination will not be given.

Breakeven (current) metered fuel cost $\left(C_{F_{0}}\right)_{\text {min }}$ A convenient economic criterion for system evaluation is the determination of those circumstances that correspond to equality of life-cycle costs for the conventional and solar-conventional systems of the $\Delta C$ equal to zero. Using this criterion and the economic and technical data described, the value of current, metered (hence, known) cost of fuel, $\left(C_{F_{0}}\right)_{\mathrm{MIN}}$, was determined as a function of total installed collector cost, $C_{0}$, and various periods of investment up to $15 \mathrm{yr}$ at each of the three locations: Albuquerque, New Mexico, Fresno, California and Caribou, Maine. The results, are given in Figs. 8 and 9. Superimposed on these results is the range of average fuel costs in the U.S. in 1981 [13]. As may be seen for a $10 \mathrm{yr}$ period of investment a solar concentrator shows economic viability at all locations for an installed collector cost of $\$ 13.00 \mathrm{ft}_{\mathrm{c}}^{-2}\left(\$ 140.00 \mathrm{~m}_{\mathrm{c}}^{-2}\right)$. At a $C_{0}$ of $\$ 20.00 \mathrm{ft}^{-2}$

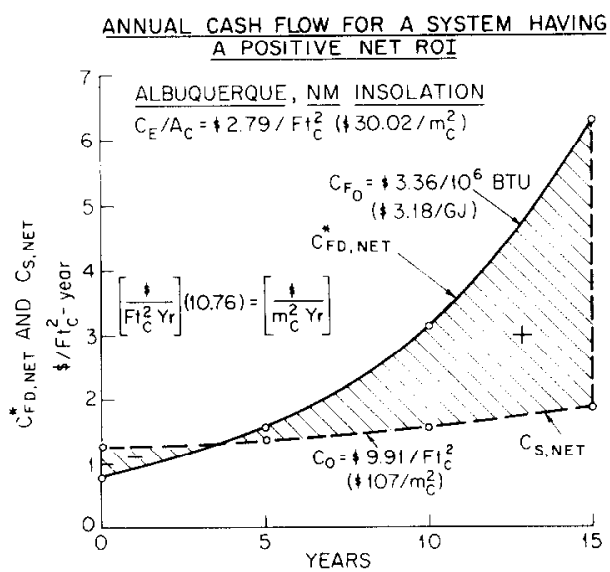

FIG. 11. Annual cash flow for a system having a positive net return on investment. Albuquerque, New Mexico insolation. $\left(\$ 215 \mathrm{~m}_{\mathrm{c}}^{-2}\right)$ a concentrator is economically viable in the western regions when in competition with liquid petroleum fuels.

Annual cash flow. Another way to represent the lifecycle economic performance of the parabolic troughs is to determine the annual dollar cash flows corresponding to the costs of ownership, (taxes, capital and maintenance) $C_{\mathrm{s}, \text { net }}$ and the costs (value) of fuel saved by the system, $C_{\mathrm{FD} \text {. nce }}^{*}$ These quantities, with their appropriate cost escalation effects, may be written

$$
\begin{aligned}
C_{\mathrm{s}, \text { net }}= & \left(1-C_{\mathrm{i}}-C_{\mathrm{T}}\right) C_{0}\left(1+C_{0} / C_{\mathrm{E}} A_{\mathrm{c}}\right) \\
\times & {\left[\left(K_{0}+T_{0}\right)\left(1-C_{\mathrm{s}}\right)(1+i)^{t}+I_{0} R_{\mathrm{s}}\right] } \\
& \$ \mathrm{ft}_{\mathrm{c}}^{-2} \mathrm{yr}^{-1}\left(\mathrm{~S} \mathrm{~m}_{\mathrm{c}}^{-2} \mathrm{yr}^{-1}\right)
\end{aligned}
$$

and

$$
\begin{aligned}
C_{\mathrm{FD}, \mathrm{net}}^{*}=\left(1-C_{\mathrm{s}}\right) \frac{C_{\mathrm{F}_{0}}}{\eta_{\mathrm{F}}}(1+a)^{t} \eta_{\mathrm{E}}\left(\frac{Q_{\mathrm{s}}}{A_{\mathrm{c}}}\right), \\
\\
\quad \$ \mathrm{ft}_{\mathrm{c}}^{-2} \mathrm{yr}^{-1}\left(\$ \mathrm{~m}_{\mathrm{c}}^{-2} \mathrm{yr}^{-1}\right) .
\end{aligned}
$$

It should be noted that $C_{\text {s.net }}$ is a function only of collector cost, $C_{0}$, for fixed economic and operational conditions and $C_{\mathrm{FD} \text {.net }}^{*}$ is a function only of $C_{F_{0}}$ for fixed economic and performance conditions. Hence, under these circumstances any values for $C_{0}$ and $C_{F_{0}}$ can be used. For the results given here in Fig. 10 the corresponding values for $C_{0}$ and $C_{F_{11}}$ at breakeven conditions have been used, namely $C_{0}=\$ 19.54 \mathrm{ft}_{\mathrm{c}}^{-2}$ $\left(\$ 210 \mathrm{~m}_{\mathrm{c}}^{-2}\right)$ and $C_{F_{v}}=\$ 3.36\left(10^{6} \mathrm{BTU}\right)^{-1}$ $\left(\$ 3.18 \mathrm{GJ}^{-1}\right)$ at Albuquerque, New Mexico.

The influence of lower collector cost, $C_{0}$, on producing a positive net return on investment is shown in Fig. 11, also for Albuquerque, New Mexico, for $C_{0}=$ $\$ 9.91 \mathrm{ft}_{\mathrm{c}}^{-2}\left(\$ 107.00 \mathrm{~m}_{\mathrm{c}}^{-2}\right)$.

\section{CONCLUSIONS}

Parabolic trough concentrators for industrial process heat application will become competitive with fossil fuels in most parts of the United States when their total installed costs per unit area of collector aperture, including auxiliary equipment, is $\$ 15.79 \mathrm{ft}_{\mathrm{c}}^{-2}$ $\left(\$ 170.00 \mathrm{~m}_{\mathrm{c}}^{-2}\right)$ for a $10 \mathrm{yr}$ period of investment under reasonable economic constraints. Recent producibility cost analyses indicate that this cost can be achieved for an advanced prototype concentrator for annual production volumes of 100000 modules, or 51600000 $\mathrm{ft}_{\mathrm{c}}^{-2} \mathrm{yr}^{-1}\left(4800000 \mathrm{~m}_{\mathrm{c}}^{-2} \mathrm{yr}^{-1}\right)$. For a total installed collector cost of $\$ 22.79 \mathrm{ft}_{\mathrm{c}}^{-2}\left(\$ 245.00 \mathrm{~m}_{\mathrm{c}}^{-2}\right)$ these parabolic troughs are competitive with fossil fuels in the western part of the U.S. for a $10 \mathrm{yr}$ period of investment. Longer periods of investment increases the economic competitiveness of solar concentrators for industrial process heat application.

Acknowledgements-The author wishes to express appreciation to Mr. Todd Anuskiewicz, President, and Mr. Indra Madan, Senior Process Engineer, of the Central Solar Energy Research Corporation, Detroit, Michigan, U.S.A., for their cooperation and assistance in the work reported here. 


\section{REFERENCES}

1. F. Kreith, J. N. Castle and C. E. Wyman, An overview of intermediate temperature solar collector and energy storage technology, in Proc. 6th Int. Heat Transfer Conf., Keynote papers Vol., pp. 255-269 (1978).

2. Concentrating Collector Mass Production Feasibility, Vol. I and II, Central Solar Energy Research Corp., Detroit, Michigan, U.S. Department of Energy, Contract No. DE-AC01-80ET-20636 (1 August 1981).

3. G. W. Treadwell, Design considerations for paraboliccylindrical solar concentrators, SAND 76-0082, VC-62, SANDIA National Laboratories, Albuquerque, New Mexico (July 1976).

4. F. Kreith and J. F. Kreider, Principles of Solar Engineering. McGraw-Hill (1978).

5. Handbook of Tables for Mathematics, 3rd edn, (edited by S. M. Selby) pp. 868-875. Chemical Rubber (1967).

6. T. D. Harrison, Midtemperature solar systems test facility program for predicting thermal performance of line-focusing, concentrating solar collectors, SAND 801964, UC-62, SANDIA National Laboratories, Albuquerque, New Mexico (November 1980).

7. J. W. Ramsey, B. P. Gupta and G. R. Knowles, Experimental evaluation of a cylindrical parabolic solar concentrator, Trans. Am. Soc. Mech. Engrs, Series C, J. Heat Transfer 99, 163-169 (1977).

8. G. W. Treadwell, N. R. Grandjean and F. Biggs, An analysis of the influence of geography and weather on parabolic trough solar collector design, SAND 79-2032, UC-2, SANDIA National Laboratories, Albuquerque, New Mexico (March 1980).

9. J. A. Clark, Solar energy economics-the a priori décision, Int. J. Heat Mass Transfer 19, 1095-1107 (1976).

10. J. A. Clark, The a priori decision in solar energy and conservation economics, Chap. 6. Vol. I, General Principles, Economics of Solar Energy and Conservation Systems (edited by F. Kreith and R. E. West), CKC Press (1980).

11. T. D. Harrison, Midtemperature solar systems test facility predictions for thermal performance based on test data, Sandia National Laboratories, Albuquerque, New Mexico. a. SAND 80-1964/10 May 1981 (Custom Engineering) b. SAND 80-1964/3 January 1981 (Acurex) c. SAND 80-1964/1 November 1980 (Solar Kinetics)

12. V. E. Dudley and R.M. Workhoven, Performance testing of the hexcel parabolic trough concentrators, SAND 78081, SANDIA National Laboratories, Albuquerque, New Mexico (1978).

13. R. B. Edelstein, Solar thermal cost goals, SERI/TP-6331063, Solar Energy Research Institute, Golden, Colorado (January 1981).

14. T. D. Harrison, G. D. Bond and A. C. Ratzel, Design considerations for a proposed passive vacuum solar annular receiver, SAND 78-0982, SANDIA National Laboratories, Albuquerque, New Mexico (April 1979).

\section{ANALYSE DES PERFORMANCES TECHNIQUES ET ECONOMIQUES D'UN CONCENTRATEUR PARABOLIQUE POUR UNE APPLICATION INDUSTRIELLE DE L'ENERGIE SOLAIRE}

Résumé - On présente une identification des facteurs principaux qui influencent la performance technique d'un concentrateur parabolique et qui se relient directement à la conception et à la construction. Ces facteurs incluent la réflectivité spectrale-directionnelle du système, le facteur d'interception miroir-récepteur tubulaire, le produit absorptivité-transmitivité du tube récepteur et du tube de converture, le facteur de perte d'extrémité et un facteur décrivant l'effet d'erreur de poursuite et de mauvais alignement du tube récepteur. Chacun de ces facteurs a été quantifié en terme de tolérance au dessin et à la fabrication et de dégradation de performance. D'autres considérations qui se relient aux pertes thermiques du tube récepteur sont le revêtement à basse émissivité et le revêtement anti-réflexion.

On développe l'analyse des coûts énergétiques. Cette analyse détermine à la fois la rentabilité, le coût de l'énergie et le cashflow annuel sur une période d'investissement allant de 5 à 15 ans. Les facteurs économiques incluent les taux d'intérêt, les coûts des systèmes auxiliaires, des fondations, des commandes, de l'installation du collecteur, de maintenance, le coût du combustible, du capital, le taux d'inflation. Des déterminations économiques sont faites à trois sites US: Albuquique NM, Fresno CA, et Caribou ME en utilisant les caractéristiques de performance thermique du collecteur prototype Sandia. Les coûts du collecteur sont ceux déterminés par une analyse basée sur des volumes de production allant jusqu’à 100.000 modules (de $48 \mathrm{~m}^{2}$ ) par an.

Les résultats montrent que pour une période d'investissement de 10 ans, le coût rentable est de $7 \$$ par GJ pour tous les sites, pour un collecteur ayant un coût total installé de $170 \$ / \mathrm{m}^{2}$, qui inclue la fabrication et linstallation $(124 \$)$, fonctions et commandes $(16 \$)$ et système auxiliaire $(30 \$)$. Pour une période d'investissement de 15 ans, les coûts correspondants de combustible sont inférieurs à $4 \$$ par GJ pour tous les sites.

Pour un total en coût de collecteur installe de $245 \$ / \mathrm{m}^{2}$, le coût rentable est inférieur à $9 \$$ par GJ en tout site, pour la même période d'investissement de 10 ans. D'autres conditions sont évaluées. L'analyse est générale et elle permet une évaluation en d'autres circonstances. 


\section{EINE TECHNISCH-WIRTSCHAFTLICHE LEISTUNGSANALYSE EINES KONZENTRIERENDEN PARABOLRINNEN-KOLLEKTORS FÜR SOLARE PROZESSWÄRME IN DER INDUSTRIE}

Zusammenfassung - Es wird die Identifikation der wichtigsten Entwurfsparameter behandelt, welche die technische Leistung eines Parabolrinnen-Kollektors beeinflussen und sich direkt auf Entscheidungen der Konstruktion und der Herstellung beziehen. Dabei werden folgende Größen berücksichtigt: Spektrale Richtungsabhängigkeit der Reflexion in einem Spiegelsystem, der Auffangfaktor von Spiegel und Absorberrohr, die Abhängigkeit vom Einstrahlwinkel und das Transmissions-Absorptions -Produkt des Absorberund des Hüllrohres, der Wärmeverlust an den Rohrenden und ein Faktor, der den EinfluB von Nachführfehlern und falscher Absorberrohr-Ausrichtung beschreibt. Jeder dieser Faktoren wurde in Form von Entwurfs- und Herstellungstoleranzen und der damit verbundenen Leistungsminderung quantitativ untersucht. Weitere Uberlegungen für die Konstruktion, die sich auf die thermischen Verluste des Absorberrohrs beziehen, sind Beschichtungen mit geringerer Emission, Evakuierung und Anti-ReflexBeschichtungen. Es wird eine Analyse der Energiekosten für konzentrierende Parabolrinnen-Kollektoren durchgeführt. In der Untersuchung werden sowohl die laufend ermittelten Kosten an der Ertragsschwelle als auch die jährlichen Betriebskosten für eine Investitionsperiode im Bereich von 5 bis 15 Jahren bestimmt. Die wirtschaftlichen Faktoren beinhalten die Steuerabzugsfähigkeit der Investitionskosten und der Kosten für Energie-Installationen, den Einkommensteuersatz, die Kosten für Hilfssystem, Fundamente und Regelung, die Kosten der Kollektorinstallation, Wartungskosten und Steuern, Brennstoffkosten, Kapitalkosten, die allgemeine Inflations- und die Brennstoffverteurungs-Rate. Die wirtschaftlichen Berechnungen wurden für drei Orte in den USA gemacht: Albuquerque, NM ; Fresno, CA; und Caribou, ME; wobei die thermische Leistungscharakteristik des "Sandia Advanced Trough Prototype"-Kollektors verwendet wurde. Die Kollekiorkosten beruhen auf Untersuchungen der Herstellungskosten für verschiedene Stückzahlen bis zu 100000 Modulen (je $48 \mathrm{~m}^{2}$ ) pro Jahr. Wie die Ergebnisse zeigen, liegen bei einem Investitionszeitraum von 10 Jahren für alle Orte die laufend ermittelten Kosten an der Ertragsschwelle bei weniger als 7,00 \$ für $10^{6} \mathrm{BTU}$. Dabei betragen die Gesamt-Installationskosten des Kollektors $170 \$ / \mathrm{m}^{2}$, die sich aufgliedern in Herstellungs- und Aufbaukosten von $123,81 \$ / \mathrm{m}^{2}$, Kosten für Fundamente und Regelung von $16,15 \$ / \mathrm{m}^{2}$ und Kosten für Hilfssysteme von $30,04 \$ / \mathrm{m}^{2}$. Für einen 15 jährigen Investitionszeitraum liegen die entsprechenden Brennstoffkosten bei weniger als $4 \$$ für $10^{6}$ BTU an allen Orten.

Für Gesamt-Installationskosten des Kollektors von $245 \$ / \mathrm{m}^{2}$ liegen die Kosten an der Ertragsschwelle bei weniger als $9 \$$ für $10^{6}$ BTU an allen Orten, ebenfalls für einen 10 jährigen Investitionszeitraum. Das Berechnungsverfahren ist allgemein gehalten, so da $B$ auch andere Faktoren berücksichtigt werden können.

\section{АНАЛИЗ ТЕХНИЧЕСКИХ ХАРАКТЕРИСТИК И ЭКОНОМИЧЕСКИХ ПОКАЗАТЕЛЕЙ ПАРАБОЛИЧЕСКОГО ЛОТКОВОГО КОНЦЕНТРАТОРА ДЛЯ ПРОМЫШЛЕННОГО ИСПОЛЬЗОВАНИЯ СОЛНЕЧНОЙ ЭНЕРГИИ}

Анпотащя-Проведен анализ основных факторов, влияюших на технические характеристики параболического лоткового концентратора, которые являются определяюцими при расчете конструкции и технологии производства. К ним относятся: спехтральная характеристика и диаграмма направленности системы зеркал, режим работы приемных зеркальных коллекторов, регулятор угла падения лучей и произведение поглощательной и пропускательной способностей прнемной и зашитной труб, козффициент концевых потерь и коэффициент, описываюций влияние ошибок неидеальности приемной трубы. Проведена количественная оценка указанных факторов на основе конструктивных н технологнчеких допусков и амортизации установки. Рассмотрены также факторы, которые определяот потери тепла присмной трубой: покрытия с низкой излучательной способностью, вакуумированные и противоотражательные покрытия.

Проведен анализ стоимости энергии при использовании параболического лоткового концентратора. В результате определены как стонмость энергии, обеспечиваюшая текупую рентабельность, так и годовые балансы для периодов капиталовложений от 5 до 15 лет. Экономические факторы включают инвестиционную налоговую скндку, налоговую скидку на энергетическое оборудование, уровень налогов на прибыль, стоимость вспомогательных систем, фундаментов и контрольных систем, стонмость монтажа, эксплуатапионные затраты и иалоги, стоимость топлива, капитала, темпы инфляции и рост цен на топливо. Экономические оценки проведены для трех районов США : Альбукерк (штат Нью-Мексико), фресно (штат Калифорния) и Карибу (штат Мэн) с использованием тепловых характеристик усовершенствонанной модели поткового коллектора, разработанного в лаборатории Сандиа. Стоимость коллектора определялась из анализа годовых затрат на производство коллекторов различных размеров вплоть до 100000 модулей (каждый плошадью 516 кв. футов $=48 \mathrm{~m}^{2}$ ).

Результаты показывают, что для 10-летнего периода капиталовложений стоимость, обеспечиваюшая текушую рентабельность, составляет менее 7 долларов на миллион БТЕ для всех районов при полной стоимости коллектора в 15,79 доллара за кв. фут (170,00 долларов за м²). Сюда входит стоимость изготовления и монтажа (11,50 доллара), фундамента, контрольных (1,50 доллара) и вспомогательных (2,79 доллара) систем. Для периода капиталовложений в 15 лет соответствующая стоимость топлива составит менее 4,00 долларов на миллио $\mathrm{bTE}$ माя всех районов.

При полной стоимости коллектора в 22,79 доллара за кв. фут (245 долларов за ${ }^{2}$ ) расчетная рентабельная стоимость топлива составит менее 9,00 долларов на миллион БТЕ дия всех районов. Это относится и к 10-летнему периопу капиталовложений. Провелена пакже оценка других условий. Анализ проводится в общем виде, что делает его пригодным для оценки других факторов. 